the nucleus for a national library away from Bloomsbury. Certainly it was a mistake for Lord Eccles, once a Minister of Education, to make the absurd declaration that "Under the existing British Museum Act, no minister has any power to move a single volume from Bloomsbury to Bayswater, or from either place to some other place". New legislation is easier to come by than are good ideas.

In the event, of course, everything will depend on what the committee under Dr F. S. Dainton recom. mends, and one of the useful products of the debate in the House of Lords was the announcement by the Government of the four members of the committee who will share the unenviable task of deciding what should happen now. They are all distinguished men, although none of them is a librarian. Their biggest difficulty in the six months or so ahead will be somehow to pick out solid ground among the mass of contradictory opinions which must surely assail them. The trustees of the museum would be well advised if they could somehow bury their chagrin at how the Government has dealt with them, for, if they fail to present a rational case for the preservation of their own version of the status quo, the chances are that the decision will go in favour of a separation between the museum and the library. Indeed, whatever strength there may be in the case the trustees have hiding up their sleeves, the advantages of a properly unified library will outweigh the advantages of a combined museum and library. In other words, there is a danger that the trustees' bluster at the way in which the Government has behaved itself will very soon seem to be bluster at the awkward implications of logic.

\section{Small Cheer for Non-proliferators}

Iт is something of a puzzle to know whether to be cheerful or otherwise about the results of the long session of the United Nations Committee on Disarmament which adjourned its meetings in Geneva last week for the Christmas holidays. For the past few weeks the chief participants at Geneva-the United States and the Soviet Union-have been suggesting that agreement on a non-proliferation treaty might have been close at hand. But it seemed to have become plain, by the end of the session, that the more cheerful predictions were based on the assumption, or perhaps the hope, that serious problems would somehow vanish. Yet there seems no real prospect of a rapid solution to the problem which dominated the last few meetings of the committee-the issue of whether the Euratom countries should be allowed to substitute to some degree inspection of nuclear installations by Euratom itself for the inspection by the International Atomic Energy Agency that will apply to everybody else. France is not, of course, represented on the committee, but it seems that the Federal Republic of Germany has not been the only sponsor of the view that Euratom inspection should be allowable. The Italian delegation at Geneva seems also to have been working for this objective.

Perhaps the most alarming feature of this development is that the European advocacy of Euratom inspection has come as such a surprise to the nuclear powers. It is now roughly a year since the argument was first raised outside the meetings of the committee on disarmament. The fact that Euratom itself seems to be in a sickly condition as a means of prosecuting research and development in nuclear energy is neither here nor there--the Euratom safeguards system is still a going concern. But the Soviet Union is unlikely to be able to agree to much less than full-blooded inspection by the International Atomic Energy Agency in Vienna. Evidently the British and American governments were hoping to take some of the edge off these proposals by announcing that civil nuclear plants in Britain and the United States would be subjected to inspection by the international agency even though nuclear powers would not formally be subjected to inspection of any kind under the terms of the treaty which have so far been negotiated. The trouble, of course, is that even such a gesture of voluntary submission may cut both ways. Although nations in Europe concerned about the supposed potential loss of commercial secrets might benefit from knowing that the United States and Britain would run similar risks, the Soviet Union is likely only to be embarrassed by this precedent, and there is no suggestion that France would be prepared to follow suit. In all these circumstances, it would not be entirely surprising if the next meeting of the disarmament subcommittee, provisionally set for January 19,1968 , is eventually postponed.

\section{Less for United States Science}

Ture war in Vietnam and the need for economic restraint at home have combined to squeeze United States spending on research and development quite drastically. Although spending in other directions has also been cut, research and development seem to have been hardest hit. In spite of a request for $\$ 5,100$ million for NASA, for example, Congress approved only $\$ 4,588$ million, the deepest cut it has ever made in the United States space effort. And the Department of Defense, although it emerges with a total budget at about the same level as last year, has been told to cut its support for basic research from $\$ 399$ million to $\$ 361$ million, more than 10 per cent. This was part of a much more drastic cut demanded for the whole Defense Department--it was asked to cut some $\$ 2,000$ million from its total budget, but only in activities unconnected with Vietnam.

Other agencies were treated more gently. The Atomic Energy Commission got an allocation of $\$ 2,509$ million, a 14 per cent increase over last year, although less than the original budget request. High energy physics research showed a $\$ 10$ million increase, and support for controlled thermonuclear fusion research went up from $\$ 22.6$ to $\$ 26.2$ million. Reactor development was increased by about 10 per cent, to $\$ 507$ million, and the Plowshare programme, which seeks to devise peaceful uses for nuclear weapons, went up from $\$ 13 \cdot 3$ million to $\$ 20.7$ million. In other departments, the rule of thumb seems to have been to cut down programmes to a size midway between the actual figures for last year and the Administration's suggestions for this. Exceptions were the individual institutes within the National Institutes of Health, which each got exactly what had been requested. The 